\title{
LOWER LEVEL OF INTERLEUKIN-6 AND HEPCIDIN FOUND IN LOWER DENSITY OF PHYSICAL EXERCISE AMONG ATHLETE DURING PANDEMIC OF COVID-19
}

\author{
Deni Purwani ${ }^{1}$, Sulistiawati Sulistiawati ${ }^{2}$, Bambang Purwanto ${ }^{3}$ \\ ${ }^{1}$ Sport and Health Science Postgraduate Program, Faculty of Medicine, Universitas Airlangga, Surabaya, \\ Indonesia \\ ${ }^{2}$ Department of Public Health, Faculty of Medicine, Universitas Airlangga, Surabaya, Indonesia \\ ${ }^{3}$ Department of Physiology, Faculty of Medicine, Universitas Airlangga, Surabaya, Indonesia
}

\section{ABSTRACT}

Pandemic of Covid-19 effected on entire daily human life in worldwide, including sport activities among athletes. An athlete was pushed to suit their routine activities with a new health protocol for Covid-19 prevention. Part of them was programed to train at home with moderate density of exercise but others was still in high density of exercise. This study was aimed to compare the serum level of hemoglobin $(\mathrm{Hb})$, interleukin-6 (IL-6) and hepcidin between athlete with high versus moderate exercise density training program during pandemic. Thirty four indoor soccer athlete of soccer football school in Malang voluntary registered as subject. Half of them received moderate exercise density exercise program, and others received high density exercise program during June-July 2020. Interleukin-6 and hepcidin level mean was found significantly lower at moderate group compared to high density group. Hemoglobin level mean was found not different between those groups. Lower density of exercise influenced on interleukin 6 and hepcidin serum level of athlete, but not on hemoglobin level.

Keywords: hepcidin, iron, exercise, covid-19, interleukin

\begin{abstract}
ABSTRAK
Pandemi Covid-19 berdampak luas terhadap semua sektor kehidupan dunia, termasuk terhadap kehidupan atlet yang aktif berolahraga. Atlet diwajbkan untuk menyesuaikan aktivitas latihan rutin dengan protokol kesehatan Covid-19. Sebagian dari atlet berlatih di rumah dengan porsi kepadatan yang dikurangi, karena takut terinfeksi penyakit Covid-19. Penelitian ini bertujuan untuk mengevaluasi kadar hemoglobin, interleukin-6 (IL-6) dan hepcidin dalam darah atlet yang memperoleh pengurangan porsi latihan dibandingkan dengan yang menerima porsi latihan tetap. Tiga puluh empat atlet futsal yang berasal dari dua kelompok SSB di Malang menjadi subjek penelitian. Sebagian dari mereka merupakan kelompok atlet yang memiliki kepadatan aktivitas berlatih tinggi (high) dan sebagian lainnya memiliki kepadatan aktivitas berlatih sedang (moderate). Kadar IL-6 dan hepcidin ditemukan lebih rendah secara bermakna dalam darah atlet kelompok atlet moderate dibandingkan dengan atlet yang high. Kadar hemoglobin tidak berbeda antara kedua kelompok atlet. Pengurangan kepadatan aktivitas berlatih atlet mempengaruhi kadar IL-6 dan hepcidin, namun tidak terhadap kadar hemoglobin.
\end{abstract}

Kata kunci: hepcidin, besi, latihan, covid-19, interleukin

Correspondence: Bambang Purwanto, Department of Physiology, Faculty of Medicine, Universitas Airlangga, Surabaya, Indonesia. Email: bambang-purwanto@ fk.unair.ac.id

pISSN:2355-8393 • eISSN: 2599-056x • doi: 10.20473/fmi.v57i2.23590

- Fol Med Indones. 2021;57:143-146• Received 02 Dec 2020 • Accepted 11 Feb 2021

- Open access under CC-BY-NC-SA license • Available at https://e-journal.unair.ac.id/FMI/ 


\section{INTRODUCTION}

Pandemic Covid-19 affected worldwide on the entire aspect of human being daily life. Sport competition was one that hardly affected during pandemic, being restricted, delayed until rejected (Yanguas et al 2020). On the other hand, athletes had to be ready to compete at anytime and anywhere. Therefore, athletes need to be prepared in the regular programed exercise. Some of them were still performed physical exercise as high as training program before pandemic, but others were reduced on density of physical exercise program for Covid-19 prevention (Lim \& Pranata 2020).

Lower density of physical exercise gave a lower load to muscle to perform contraction (Moreira et al 2014). Muscle adapted to physical load by secreting interleukin-6 in to blood stream. Interleukin-6 is an important myokine for muscle adaptation during exercise (Chowdhury et al 2020). It responsible for inflammatory modulation, protein synthesis, lipid deposition, metabolism and muscle development. Interluekin-6 was also associated to iron deposition involving ferritin, hepcidin and hemoglobin (Nakagawa et al 2014).

The pandemic Covid-19 was nine months long in Indonesia, but the effect of physical training program alteration on iron homeostasis among athletes during pandemic was still unclear. This study was aimed to compare level of blood hemoglobin and hepcidin among group of athletes who done regularly high density of exercise versus those who done regularly moderate density of exercise. We also performed interleukin-6 level examination in the athlete blood to explain its association with inflammation.

\section{MATERIALS AND METHODS}

The research was a comparative study among 62 subjects. Subjects were healthy male professional indoor soccer (futsal) athlete, 20-23 years of age. They were voluntary registered from Futsal Club in Malang, East Java, Indonesia. During pandemic, Club distinguished athletes in two different groups. Those who lived inside dormitory and the outside. We characterized both groups of athletes in age, body weight, body mass index and physical exercise density score of GPAQ.
Athletes were taking $3 \mathrm{ml}$ blood sample from mediana cubiti vein for hemoglobin, hepcidin and inerleukin-6 level examination. The examination of hepcidin and interleukin-6 level were using ELISA method, performed at Physiology laboratory of Universitas Brawijaya, Malang. The hemoglobin level was examined using POCT method at the time of blood sampling.

All procedures had been clear ethically stated by Health Research Ethics Committee, Faculty of Medicine Universitas Airlangga No. 72/EC/KEPK/FKUA/2020.

\section{RESULTS}

Subject characteristic between groups were different in body weight and physical exercise density of GPAQ score. but not different in age and body mass index. Dormitory residence characterized as lower in body weight but higher in exercise density compared to nondormitory residence. The score of GPAQ confirmed that athlete of non-dormitory residence performed exercise at lower density (moderate level) compared to athlete of dormitory residence (high level). It could be seen at Table 1 as follows.

The Mann Whitney test was performed to compare variables between groups. Blood hepcidin and interleukin-6 level were lower among non-dormitory athlete compared to dormitory athlete. Lower level of blood hepcidin and interleukin-6 were found at lower density of physical activity (GPAQ score). Fortunately, blood hemoglobin was not different between groups. It could be seen at table 2 as follows.

Table 1. Subject characteristics

\begin{tabular}{lcc}
\hline & \multicolumn{2}{c}{ Mean \pm Standard Deviation } \\
\cline { 2 - 3 } Characteristics & Non-Dormitory & Dormitory \\
\hline Age (years) & $22.64 \pm 1.22$ & $21.82 \pm 3.12$ \\
Body Weight $(\mathrm{kg})^{*}$ & $61.52 \pm 9.36$ & $57.41 \pm 3.35$ \\
IMT $(\mathrm{kg} / \mathrm{m}$ square) & $20.85 \pm 2.11$ & $20.65 \pm 1.53$ \\
Exercise density of & $3504.31 \pm 5.52$ & $7523.22 \pm$ \\
GPAQ score (Mets & (moderate & 12.56 \\
min/week)* & level) & (high level) \\
\hline
\end{tabular}

*Significantly different at $\mathrm{p}<0.05$ 
Table 2. Comparison variables between groups

\begin{tabular}{lccc}
\hline \multirow{2}{*}{ Variables } & \multicolumn{2}{c}{ GPAQ score } & Sig \\
& Moderate level & High level & $(\mathrm{p})$ \\
\cline { 2 - 3 } hemoglobin level $(\mathrm{mg} / \mathrm{dl})$ & $16.02 \pm 1.14$ & $15.67 \pm 1.14$ & 0.236 \\
$\mathrm{IL}-6$ level $(\mathrm{ng} / \mathrm{ml})$ & $491.77 \pm 198.43$ & $688.74 \pm 237.91$ & $0.009 *$ \\
hepcidin level $(\mathrm{ng} / \mathrm{ml})$ & $145.70 \pm 39.11$ & $188.69 \pm 49.85$ & $0.037^{*}$ \\
\hline
\end{tabular}

*Significantly different at $\mathrm{p}<0.05$

\section{DISCUSSION}

Pandemic of Covid-19 pushed sport activities meet a new normal in exercise, training, event and competition. Unfortunately, there was not any standardized protocol for athlete to perform physical exercise during pandemic. Particular athlete was homed for training from home program, but others was still in dormitory of training center camp. We compared between groups for characteristics and the level of blood hemoglobin, hepcidin and interleukin- 6 during 6 months of training.

Body weight of athlete who trained from home was higher than those in training center camp. There was not any nutritional control of diet balance at home. Homing athlete felt free to eat and drink whatever they wanted without any tight rules as in training center camp. It ruined the physical conditioning program of head coaches in order to maintain athlete's physical fitness. More in kilograms of body weight raised more in oxidative stress marker in the blood (Huang et al 2015). It potentially destructed erythrocyte membrane and hemoglobin impairment level in chronic (Pagani et al 2019).

Fortunately, we found that hemoglobin level between groups were not different during six months of training. Both were still in normal standard level of athlete hemoglobin; therefore, there was no need to worry. New habituation of six month at home did not significantly alter homeostasis of iron metabolism of trained athlete. Endogenous anti-oxidant defense of trained athlete was three-fold higher than those untrained subjects. Six months of training from home program during pandemic did not alter redox balance between endogenous anti-oxidant defense versus radical oxidant in both groups of athletes.

Homed athletes performed moderate density of physical exercise at $3000-6000$ mets min/ week. Moderate exercise at $60 \%$ of max heart rate increased all antioxidant proteins level after 12 weeks of training. It was needed to protect erythrocyte membrane plasma against lipid per oxidized destruction and systemic inflammation. We found that blood interleukin-6 level of homed athlete was lower than those athletes in dormitory of training center camp.

Interleukin-6 was a pro-inflammatory cytokine that eventually raised following physical exercise (White et al 2020). Higher level of interleukin-6 explained in high response of inflammation due to physical exercise (Cabral-Santos et al 2015). Interleukin-6 stimulated synthesis of hepcidin so that its level raised up in the blood during inflammation (Nemeth et al 2004, D'Angelo 2013). The effect of exercise intensity and volume on the interleukin-6 response was significantly increase in the high intensity group compared to the low intensity group (Cullen et al 2016). Training from home program resulted lower level of blood hepcidin due to lower level of interleukin-6.

Hepcidin played key role of ferroportin opening and iron transport via membrane regulation (Coates 2014). Hepcidin inhibited ferroportin opening so that iron failed to export across membrane of erythrocyte and macrophage (Ganz \& Nemeth 2012). Higher level of hepcidin found in chronic iron deficiency anemia among athlete. Significant higher level of blood hepcidin and interleukin-6 was found among rowing athletes after high intensity training program. Iron serum level was dropped in to low level of iron deficiency anemia (Skarpańska-Stejnborn et al 2015). The intensity exercise $>65 \%$ of VO2max induces an increase hepcidin levels and reaches its maximum level when the intensity of exercise is $90 \%-95 \%$ VO2max (Peeling et al 2009). We found lower level of blood hepcidin and normal hemoglobin among athlete who trained from home with moderate physical density of exercise.

\section{CONCLUSION}

Athletes with six months trained from home performed moderate density of physical exercise. Blood interleukin-6 and hepcidin were found in lower level. It helped to maintain hemoglobin level was still in high standard of professional level. 


\section{ACKNOWLEDGMENT}

This study was granted by Penelitian Unggulan Fakultas research scheme program of Faculty of Medicine, Universitas Airlangga, Surabaya 2020.

\section{REFERENCES}

Cabral-Santos C, Gerosa-Neto J, Inoue DS, et al (2015). Similar anti-inflammatory acute responses from moderate-intensity continuous and high-intensity intermittent exercise. Journal of Sports Science and Medicine 14, 849-856.

Chowdhury S, Schulz L, Palmisano B, et al (2020). Muscle-derived interleukin 6 increases exercise capacity by signaling in osteoblasts. Journal of Clinical Investigation 130, 2888-2902.

Coates TD (2014). Physiology and pathophysiology of iron in hemoglobin-associated diseases. Free Radical Biology and Medicine 72, 23-40.

Cullen T, Thomas AW, Webb R, et al (2016). Interleukin- 6 and associated cytokine responses to an acute bout of high-intensity interval exercise: The effect of exercise intensity and volume. Applied Physiology, Nutrition and Metabolism 41, 803-8.

D'Angelo G (2013). Role of hepcidin in the pathophysiology and diagnosis of anemia. Blood Res 48, 10-15.

Ganz T, Nemeth E (2012). Hepcidin and iron homeostasis. Biochimica et Biophysica Acta Molecular Cell Research 1823, 1434-43.

Huang CJ, McAllister MJ, Slusher AL, et al (2015). Obesity-related oxidative stress: The impact of physical activity and diet manipulation. Sports Medicine - Open 1, 1-12.
Lim MA, Pranata R (2020). Sports activities during any pandemic lockdown. Irish Journal of Medical Science 4, 1-5.

Moreira LDF, de Oliveira ML, Lirani-Galvão, et al (2014). Physical exercise and osteoporosis: effects of different types of exercises on bone and physical function of postmenopausal women. Arquivos Brasileiros de Endocrinologia \& Metabologia 58, 1-9.

Nakagawa H, Tamura T, Mitsuda Y, et al (2014). Inverse correlation between serum interleukin-6 and iron levels among Japanese adults: A cross-sectional study. BMC Hematology 14, 1-6.

Nemeth E, Rivera S, Gabayan V, et al (2004). IL-6 mediates hypoferremia of inflammation by inducing the synthesis of the iron regulatory hormone hepcidin. Journal of Clinical Investigation 113, 1271-6.

Pagani A, Nai A, Silvestri L, et al (2019). Hepcidin and Anemia: A Tight Relationship. Frontiers in Physiology 10, 1-7.

Peeling P, Dawson B, Goodman C, et al (2009). Training surface and intensity: Inflammation, hemolysis, and hepcidin expression. Medicine and Science in Sports and Exercise 41, 1138-45.

Skarpańska-Stejnborn A, Basta P, Trzeciak J, et al (2015). Effect of intense physical exercise on hepcidin levels and selected parameters of iron metabolism in rowing athletes. European Journal of Applied Physiology 115, 345-351.

White GE, West SL, Caterini JE, et al (2020). Massage therapy modulates inflammatory mediators following sprint exercise in healthy male athletes. Journa of Functional Morphology and Kinesiology 5, 1-11.

Yanguas X, Dominguez D, Ferrer E, et al (2020). Returning to sport during the covid-19 pandemic: The sports physicians' role. Apunts Sports Medicine 55, 49-51. 